\title{
CAR T-Cell Immunotherapy in Human and Veterinary Oncology: Changing the Odds Against Hematological Malignancies
}

Jonathan P Mochel ${ }^{1}$, Stephen C Ekker ${ }^{2}$, Chad M Johannes ${ }^{3}$, Albert E Jergens ${ }^{3}$, Karin Allenspach $^{3}$, Agnes Bourgois-Mochel ${ }^{3}$, Michael Knouse ${ }^{1}$, Sebastien Benzekry ${ }^{4}$, Wesley Wierson ${ }^{5}$, Amy K LeBlanc ${ }^{6}$, Saad S Kenderian ${ }^{7,8}$

${ }^{1}$ Iowa State University, Department of Biomedical Sciences, Ames, IA 50011, USA.

${ }^{2}$ Mayo Clinic Cancer Center Department of Biochemistry and Molecular Biology, Rochester, MN 55905, USA.

${ }^{3}$ Iowa State University, Department of Veterinary Clinical Sciences, Ames, IA 50011, USA.

${ }^{4}$ Institut National de Recherche en Informatique et en Automatique, Team MONC, Bordeaux, France.

${ }^{5}$ Iowa State University, Department of Genetics, Development, and Cell Biology, Ames, IA 50011, USA.

${ }^{6}$ Comparative Oncology Program, Center for Cancer Research National Cancer Institute, Bethesda, MD 20892, USA.

${ }^{7}$ Mayo Clinic Division of Hematology, Department of Medicine, Rochester, MN 55905, USA. ${ }^{8}$ Department of Immunology, Mayo Clinic, Rochester, MN 55905.

Running head: CAR T-Cell Immunotherapy in Comparative Oncology

\section{Correspondence:}

Jonathan P. Mochel, DVM, MS, Ph.D, DECVPT

Associate Professor of Pharmacology

lowa State University College of Vet. Medicine

2448 Lloyd, 1809 S Riverside Dr.

Ames, IA 50011-1250

Phone 515-294-7424

Email: imochel@iastate.edu 


\section{Abstract}

3 The advent of the genome editing era brings forth the promise of adoptive cell transfer using 4 engineered chimeric antigen receptor (CAR) T-cells for targeted cancer therapy. CAR T-cell 5 immunotherapy is probably one of the most encouraging developments for the treatment of 6 hematological malignancies. In 2017, two CAR T-cell therapies were approved by the U. S Food and 7 Drug Administration; one for the treatment of pediatric Acute Lymphoblastic Leukemia (ALL), the other 8 for adult patients with advanced lymphomas. However, despite significant progress in the area, CAR 9 T-cell therapy is still in its early days and faces significant challenges, including the complexity and 10 costs associated with the technology. B-cell lymphoma is the most common hematopoietic cancer in 11 dogs, with an incidence approaching $0.1 \%$ and a total of $20-100$ cases per 100,000 individuals. It is a 12 widely accepted naturally occurring model for human non-Hodgkin's lymphoma. Current treatment is 13 with combination chemotherapy protocols, which prolong life for less than a year in canines and are 14 associated with severe dose-limiting side effects, such as gastrointestinal and bone marrow toxicity. 15 To date, one canine study generated CAR T-cells by transfection of mRNA for CAR domain 16 expression. While this was shown to provide a transient anti-tumor activity, results were modest, 17 indicating that stable, genomic integration of CAR modules is required in order to achieve lasting 18 therapeutic benefit. This Commentary summarizes the current state of knowledge on CAR T-cell immunotherapy in human medicine and its potential applications in animal health, while discussing the potential of the canine model as a translational system for immuno-oncology research.

21 Keywords: Immuno-Oncology; CAR T-cell; Lymphoma; One Health. 


\section{Introduction}

Research in cancer immunotherapy has two major current and complementary approaches: (1) immune checkpoint inhibitors such as those that recently garnered a Nobel Prize in Medicine [1], and (2) chimeric antigen receptor (CAR) T-cell programming. The former focuses on activation of intrinsic properties of T-cells. The latter involves the exogenous 'education' of $\mathrm{T}$ cells to seek-out and target cells expressing a particular antigen found on specific cancer cell types [2]. These methods are considered complementary, and progress on combining these approaches is being reported [3]. Cancer immunotherapy is an extremely promising new approach in oncology that has the profound potential for curative endpoints. CAR T-cell therapies are particularly promising for hematologic malignancies, garnering two FDA approvals in 2017 [4,5] representing the first for both these classes of immunotherapies in addition to serving as the inaugural class of gene therapybased strategies. Over 700 potential Investigative New Drug applications are in the queue for cellular and/or gene therapy applications [6] demonstrating the sustained future for these classes of drugs in the therapeutic pipeline. B-cell neoplasms are the most common hematopoietic cancer in both humans and dogs [7]. In canine, genetic background can impact disease onset and progression as some breeds show a substantially higher risk of this blood disease, including 11 small-breed dogs, with English Bulldogs presenting years earlier than the overall cohort [8].

The present Commentary provides a review of the current knowledge on the biology of CAR T-cell therapy and its current applications in human oncology. With the success at treating B-cell lymphoma using CAR T-cell therapies in people, and the conserved nature of the blood systems between dogs and humans, this review also provides a perspective for developing these and related living therapies for conquering canine cancer.

\section{Definition and Process of Manufacturing CAR T-cells for Cancer Therapy}

\section{What are CAR T-cells?}

The original CAR structure was described in 1989 and included a receptor fused to a signaling

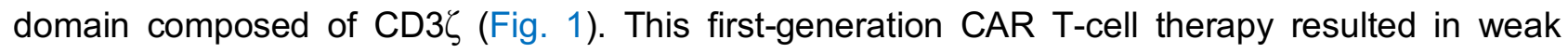
proliferation, short survival and limited anti-tumor effect in patients [9-11]. Subsequently, it was found that T-cells require a second signal for full activation and, therefore, second-generation CAR T-cells were developed, with two recently FDA approved products in the U.S and Europe. The structure of this new CAR includes a co-stimulatory molecule (e.g. CD28 or 4-1BB) that leads not only to improved expansion and persistence but also to superior anti-tumor effect $[12,13]$. The basic second-generation CAR T includes an antigen-binding domain, usually derived from a single chain variable fragment (scFv) or a protein receptor, a hinge that connects the scFv to a transmembrane domain, a co-stimulatory domain, and a CD3 $\zeta$ signaling domain. This allows for antigen presentation 
bypassing the major histocompatibility complex and results in direct activation of $\mathrm{T}$ cells upon exposure to tumor surface antigens. In most cases, the scFv has been murine derived and been implicated in anti-CAR cytotoxic T-cell responses upon subsequent CAR T infusion, rendering them ineffective $[14,15]$. It is hypothesized that such responses against autologous T-cells expressing CAR transgene may be less pronounced with the human derivatives.

The transmembrane hinge region allows for optimal structure of antigen binding while the activation domains direct CAR T-cell phenotype and function into specific ways. CD28 and 4-1BB (CD137) are the two most commonly used co-stimulatory molecules thus far. CD28 is a member of the immunoglobulin family of co-stimulatory receptor, which also includes cytotoxic T-lymphocyte associated antigen-4 and programmed death receptor (PD-1). The extracellular domain of CD28 binds to B7 proteins and initiates the co-stimulatory signal transduction [16]. CD28 signaling increases the effect of T-cell and receptor antigen engagement and results in proliferation of $\mathrm{T}$ cells at otherwise sub-mitogenic antigen concentrations [17]. Consequently, cytokine production, most importantly IL-2, is significantly increased. Therefore, CD28 co-stimulation increases cell survival by inducing expression of anti-apoptotic proteins such as $B c l-X_{L}$ [18]. 4-1BB, on the other hand, is a member of the TNF receptor family and is expressed primarily on activated lymphocytes. It results in proliferation and differentiation of CD8+ T cells, while inhibiting programmed cell death [19]. While CD28:B7 co-stimulation expands naïve T-cells, 4-1BB co-stimulation expands memory T-cells, resulting in enrichment of antigen-reactive T-cells upon recognition of previously primed antigens. Co-stimulation with 4-1BB domain has shown enhanced in vivo persistence, higher expansion and enhanced cytolytic ability compared to CD28 co-stimulation $[19,20]$. It has also been suggested that combining these 2 co-stimulatory domains result in a more efficient and persistent anti-tumor activity, by combining their strengths of early tumor-killing with late persistence and engraftment. This has led to the concept of third-generation CAR that now include 2 co-stimulatory domains along with the activation domain, resulting in $\geq 3$ signaling domains in the CAR T structure [21]. To date, the incorporation of more stimulatory domains did not enhance CAR T-cell function in preclinical or early clinical trials. This evolution at an unprecedented pace in the world of immuno-oncology has generated a tremendous enthusiasm and has led to an exciting time for developing new strategies for cancer treatment.

\section{T Cell isolation, expansion and generation of CAR T-cells}

The following steps are required to generate clinical grade CAR T-cells (Fig. 2):

1) T-cells are collected from patients by leukapheresis;

2) T-cells are then cultured in a good manufacturing process-compliant facility;

3) T-cells are stimulated using stimulating beads, antibodies or artificial antigen presenting cells; 
4) T-cells are transduced with the CAR of interest. At this stage, the non-tumor specific T cells acquire the ability to recognize tumor antigens;

5) To insert the CAR gene into T-cells, viral vectors (lentivirus or retrovirus), or non-viral approaches are used (transposon, CRISPR, TALEN, RNA). While the use of viruses raises concerns for insertional mutagenesis, third generation lentiviruses have been shown to be safe after decades of follow-up;

5) T-cells are cultured for a period of 7-14 days. During that time, they expand by several folds and express the CAR T construct of choice;

6) The final product needs to pass pre-specified release criteria (i.e. sterility, safety, efficacy) and is then cryopreserved for future infusion into patients;

7) Patients receive low-dose lymphodepleting chemotherapy, followed by infusion of the CAR T cells.

After infusion, CAR T-cells are stimulated through the CAR receptor after they recognize their target antigen on tumor cells. This is followed by a massive in vivo T-cell expansion, associated with cytokine release, and the release of toxic granules (Fig. 3). During this time, T-cells exhibit their antitumor effect and patients are at risk of developing clinical cytokine release syndrome. Following expansion, T-cells contract and, in some instances, differentiate into a memory phenotype.

\section{Applications in Human Oncology}

CD19 targeting CAR T-cell has been the most successful therapy to date in relapsed/refractory acute lymphoblastic leukemia (ALL). In the pre-CAR T therapy era, prognosis of relapsed/refractory B-cell ALL has been dismal with median overall survival reported in few weeks-months and survival at 5 years around 7-8\% [22-24]. B-cell ALL was the first indication for which any CAR T therapy was approved by the U.S FDA. Tisagenlecleucel (previously CTL019) was the first gene FDA-approved therapy for the treatment of relapsed/refractory B cell ALL in patients up to 25 years of age. The initial report included 2 children from the University of Pennsylvania, one of whom had an ongoing response at 11 months follow-up (and we know is ongoing to date), while the other relapsed with CD19 negative blast cells after an ephemeral response lasting for 2 months [25]. In the subsequent report of 30 patients with relapsed/refractory ALL, 27 (90\%) patients achieved a complete response and $22(73 \%)$ patients had no detection of disease using sensitive multiparametric flow cytometry at 1 month after infusion [26]. Interestingly, one patient had relapsed T-cell ALL post-transplantation with aberrant CD19 expression and achieved a morphological response with tisagenlecleucel but with only minimal residual disease. Data from clinical trials were expanded from single center experience to multicenter studies with the ELIANA trial that included 92 patients; $75(82 \%)$ of which received infusion of tisagenelecleucel [5]. Remission was noted in $83 \%$ patients with overall survival rate of $90 \%$ at 6 
months and $76 \%$ at 12 months. From the intention-to-treat analysis of 92 enrolled patients, complete response (with or without complete hematological recovery) was observed in $66 \%$ patients.

Following the remarkable activity in ALL, trials with CART19 cell therapy were initiated in B-cell lymphomas. Diffuse large B-cell lymphoma (DLBCL) is a heterogeneous group within Non-Hodgkin's lymphomas $(\mathrm{NHL})$ with varying molecular profiles, gene sequencing patterns and clinical responses; some of which are associated with poorer outcomes and represent an area of therapeutic unmet need. Clinically, patients who achieved stable or progressive disease as best response during the entire course of therapy, or those who relapsed within 12 months of autologous stem cell transplantation, have been shown to have a rather low overall survival rate of around 6.3 months [27]. The now FDA-approved axicabtagene-ciloleucel (KTE-019) therapy was initially developed at the National Cancer Institute $(\mathrm{NCl})$. Preclinical work done at the $\mathrm{NCl}$ consisted of developing CARtransduced T-cells that could specifically recognize murine CD19 and resulted in eradication of intraperitoneally injected lymphoma cells and subcutaneous lymphoma masses in a murine model [28].

Subsequent clinical studies showed an objective positive response in $75-80 \%$ patients treated with axicabtagene-ciloleucel, including some longer lasting responses [29]. This construct was further pursued by Kite Pharma, as KTE-019, in the famous ZUMA-1 trial which paved the way for FDA approval of this modality for DLBCL. The Phase 1 part of the ZUMA trial enrolled 7 patients with 1 patient experiencing a dose limiting toxicity, while grade $\geq 3$ cytokine release syndrome (CRS) and neurotoxicity were reported in $14 \%$ and $57 \%$ patients, respectively. In this report, 5 out of the $7(71 \%)$ patients showed an objective positive response, with 4 (57\%) being complete responses. The Phase 2 ZUMA-1 study enrolled 111 patients, of whom 101 were able to receive the CAR T-cell infusion [4]. Overall positive response was reported in $82 \%$ patients with a complete response in $54 \%$ of the cases. Complete response was maintained in $40 \%$ patients at a median follow-up of 15.4 months. Of the 108 patients who had at least 1 year follow-up in Phase 1 and Phase 2 of the ZUMA-1 trials, an overall response was seen in $82 \%$ patients, with a complete response in $58 \%$ of the cases. Of the 60 patients who had a partial response or a stable disease at the first assessment 1 month post CAR T-cell therapy, 23 had a subsequent complete response. The progression free survival rate was estimated at $49 \%$ in patients at 6 months, $44 \%$ at 12 months and $41 \%$ at 15 months, while the overall survival rate was $78 \%, 59 \%$ and $52 \%$ at 6,12 and 15 months, respectively. Response to treatment was not affected by CD19 expression intensity, CD4-to-CD8 cell ratio, or the use of tocilizumab; but was associated with a higher expansion of CAR T-cells instead. However, CAR T-cell expansion within the first 28 days was noted to be higher in patients who had a positive response compared to those who did not. One-year follow-up data presented at the Annual Meeting of the American Society of Hematology and the Bone Marrow Transplantation Tandem Meetings in 2018 [30] suggested loss 
160

161

162

163

164

165

166

167

168

169

170

171

172

173

174

175

176

177

178

179

180

of CD19 expression and gain of PD-L1 expression as possible mechanisms for resistance following CAR T-cell therapy. Another product, tisagenlecleucel (CTL019), is now FDA-approved for use in patients with relapsed/refractory DLBCL (not including primary mediastinal large cell lymphoma). Approval was based on a Phase 2 study (JULIET) that enrolled 160 patients with primary analysis available on 81 patients with at least 3 month follow-up or earlier discontinuation [31]. Best overall response rate was $53.1 \%$ in these evaluable patients $(39.5 \%$ complete response and $13.6 \%$ partial response). At 6 months, probability of being relapse-free was estimated at $73.5 \%$ with an overall survival of $64.5 \% .95 \%$ patients in complete response at 3 months also maintained positive response at 6 months. Another case-series for the same product enrolled 38 patients with DLBCL or follicular lymphoma, of which 28 were able to receive cell infusion [32]. At 3 months, 18 of the 28 patients had a positive response (64\%). Three patients with follicular lymphoma and 1 patient with DLBCL who had partial response at 3 months had a complete response by 6 months. At 6 months, 16 out of 28 $(57 \%)$ patients had a complete response and these remained in remission at a median time of 29.3 months (range: 7.7 - 37.9 months). In this study, peak expansion of CAR T-cells was not different between patients who responded compared to those who did not.

Overall, multiple CD19 targeting CAR T-cell therapy constructs are currently in development and expected to receive FDA approvals for different $B$ cell malignancies in the next 2-3 years. One example is the B-Cell Maturation Antigen (BCMA) directed CAR T-cell therapy which is showing promising activity in multiple myeloma [33].

\section{Unique Toxicities of CAR T-Cell Therapy}

Due to its specific mode of action, CAR T-cell therapy is associated with various adverse effects, including the development of cytokine release syndrome, neurotoxicity and B-cell aplasia resulting in hypogammaglobulinemia.

\section{Cytokine Release Syndrome}

Cytokine release syndrome (CRS) is one of the most feared toxicities related to CAR T-cell therapy. As its name suggests, CRS is a systemic inflammatory state resulting from the excessive production of cytokine associated with CAR T-cell activation. Time-to-development of CRS is widely variable and depends on the CAR construct, the disease type and the tumor burden. Rates of CRS have ranged from 45 to $100 \%$ in various reports with serious or $\geq 3$ grade in up to $50 \%$ of patients [34]. Clinical manifestations can range from mild fever to life-threatening vasodilatory shock causing hypoxia, hypotension and organ toxicity mandating management in the intensive care unit. Death related to $\mathrm{CRS}$ has been reported $[4,14,35]$. It has also been suggested that a higher burden of tumor antigens may be associated with higher rates and severity of CRS [36]. Various biomarkers 
194

195

196

have been studied to elucidate the mechanism, of which interleukin(IL)-6/ IL-6 receptor interaction has been most consistently shown to correlate with CRS. Consistently, blockade of the IL-6 pathway has resulted in alleviation of symptoms related to CRS [37]. C-reactive protein and ferritin are clinically available laboratory tests that have been shown to be elevated in patients who develop CRS and are monitored closely at some institutions, including the Mayo Clinic Cancer Center $[38,39]$. Other cytokines associated with inflammation such as interferon-gamma, soluble IL-2 receptor and IL-10 have been implicated. Teachey et al. [40] at the University of Pennsylvania identified a set of 24 cytokines, including interferon-gamma, IL-6, and soluble glycoprotein-130 that

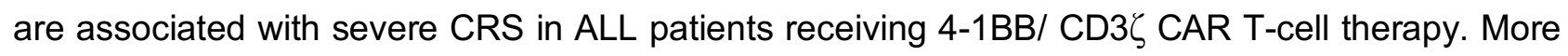
recently, studies in murine models of CRS have demonstrated that the severity of CRS does not only depend on CAR T-cell derived cytokines but also on IL-1, IL-6 and nitric oxide release by host macrophages [41]. This finding can potentially open additional avenues for preventative or therapeutic measures. Currently, the mainstay of treatment for CRS remains tocilizumab since its use in the first patient treated with CART19 for ALL [25]. Subsequent data showed that the use of tocilizumab for CRS does not adversely affect the expansion of CD28/CD3 $\zeta$ CAR T-cells, unlike that of high-dose steroids [38]. Another agent of potential utility for this indication is siltuximab which, in contrast to tocilizumab, directly inhibits IL-6. This direct inhibition may result in less reliance on competitive binding to IL-6 receptor and eliminate the risk of passive diffusion of unbound IL- 6 into the central nervous system (CNS) resulting in neurotoxicity [42].

\section{Neurotoxicity}

The risk of neurotoxicity with CAR T-cell therapy became apparent when 5 patients died of cerebral edema in one of the early phase ROCKET trial being conducted by Juno Pharmaceuticals using JCAR015 in adult patients with B-cell ALL. Additional deaths have been reported in both Bcell ALL and NHL trials [14,39]. Non-fatal but clinically significant neurotoxicity has additionally been reported in around $40-50 \%$ patients across various clinical trials with the different CAR constructs in various malignancies [43]. Clinical presentation can vary from headache, confusion, tremor, to delirium, expressive aphasia, obtundation, myoclonus or seizure. Whether there are pre-existing risk factors in the form of CNS disease is currently unknown, as patients with active CNS disease were typically excluded from clinical trials. Various hypotheses have been put forth to explain the development of neurotoxicity, but the exact mechanism remains elusive. One hypothesis is that CAR T-cell activation results in elevated cytokine levels triggering macrophage activation and subsequent neurotoxicity. More recently, with the use of the CD28-CD3 $\zeta$ therapy in lymphoma, IL10 as well as IL-15 were noted to achieve higher peak levels in patients with grade 3 or 4 neurotoxicity compared to those with $<$ grade 3 neurotoxicity [44]. Endothelial activation and 
multifocal vascular lesions, resulting in disruption of the blood-brain-barrier were reported in patients experiencing neurotoxicity within 28 days of infusion with CD19 CAR T-cells in B cell ALL, NHL and CLL [45]. Humanized mice model studies have shown a role for IL-1 and IL-6 derived from host monocytes in neurotoxicity which would provide a rationale for the use of anakinara (IL-1 receptor antagonist) in this indication [41]. However, the mainstay of therapy to resolve CAR T-associated neurotoxicity remains corticosteroids.

\section{Hypogammaglobulinemia}

B-cell aplasia is an example of 'on-target/off-tumor' activity of CAR T-cell therapy since CD19 is expressed not only on the malignant B-cells but also on normal B-lymphocytes. B-cells are assigned with the task of producing immunoglobulins and hence, B-cell aplasia following CAR T-cell therapy results in prolonged hypogammaglobulinemia. Hence, it is not surprising that all patients from the University of Pennsylvania ALL cohort who had a positive clinical response to CAR T-cell therapy also developed B-cell aplasia [5]. Hypogammaglobulinemia leads to an increased risk of infections and the need for regular intravenous immunoglobulin replacement for the duration of B-cell aplasia.

\section{Applications in Veterinary Oncology}

\section{A critical need for new and innovative therapies in canine B-cell lymphoma}

It is estimated that more than 4.2 million dogs (5300/100,000 per population rate) in the U.S are diagnosed with cancer each year [46]. The epidemiology of canine cancer is, however, not well defined in the literature. Most of the available incidence data comes from a limited number of tumor registries and the European Union where there is a higher percentage of insured dogs. Very little to no published data is available to indicate what percentage of dogs diagnosed with cancer are then treated or how they are treated in the U.S. This makes any assessment of the actual market potential for veterinary oncology therapeutics extremely challenging. Clinical experience would indicate that the most common canine malignant cancers diagnosed and treated include lymphoma, mast cell tumor, osteosarcoma, soft tissue sarcoma, hemangiosarcoma and melanoma.

This clinical impression is supported by a Swiss Canine Cancer Registry study that outlined the most common neoplasms diagnosed in over 120,000 dogs during a 53-year period as follows: adenoma/adenocarcinoma (18.09\%), mast cell tumor $(6.5 \%)$, lymphoma $(4.35 \%)$, melanoma (3.63\%), fibroma/fibrosarcoma (3.40\%), hemangioma/hemangiosarcoma $(2.80 \%)$, squamous cell carcinoma (1.95\%) and osteoma/osteosarcoma (1.24\%) [47]. The high occurrence of carcinoma (mammary) is related to the less frequent implementation of ovariohysterectomy at a young age which is more common in the U.S. 
Lymphoma, with an estimated incidence rate of 20-100 per 100,000 dogs [48], is one of the most widely treated canine cancers given its frequent occurrence and typically robust response to chemotherapeutics. Based on the current approximation of 75 million dogs in the U.S, estimates are that $16,000-80,000$ new cases of canine lymphoma are diagnosed each year [49]. Other estimates place the number of diagnosed canine lymphoma cases at over 250,000 annually in the U.S, accounting for $12-18 \%$ of annual death-related malignant cancers in dogs [46]. This makes the canine lymphoma market a very appealing potential opportunity for therapeutic development. There is abundant recent literature highlighting the pathologic, biologic, immunophenotypic, genetic and treatment response similarities between human and canine lymphoma [49-52]. Specifically, DLBCL is the most common subtype of lymphoma in both species [52], and it is the subtype most studied with genomic profiling in veterinary medicine [46]. Utilizing immunohistochemistry and gene expression profiling, similar profiles were noted between human and canine DLBCL, and certain markers were able to separate the canine DLBCL cases into two groups with significantly different clinical outcomes [53]. Provided this robust and expanding body of data supporting the parallels between the most common types of human and canine lymphoma, the opportunities for therapeutic development in one species to inform and progress that in the other species will only continue to grow.

The majority of canine cancer treatments rely on the use of human generic chemotherapeutics. The clinical responses to these therapeutics for the most common canine cancers (lymphoma, osteosarcoma, hemangiosarcoma) have remained static for the past 10-20 years.

Focusing on canine B-cell lymphoma in particular, the standard of care for dogs with high grade lymphoma over the last 35 years has ranged from single agent protocols (using prednisone or doxorubicin) to combination chemotherapy regimens of variable duration. Most veterinary oncologists agree that a doxorubicin-based (e.g. CHOP) combination chemotherapy protocol provides the longest period of disease control and overall survival [54]. However, the response to chemotherapy is often sub-optimal with recurrent or refractory disease representing a significant clinical challenge. The combination of chemotherapy with half- and total-body irradiation has also been evaluated in some dogs with lymphoma. The reported median survival rate in these instances is no longer than that achieved with chemotherapy alone, thereby questioning the utility of this adjunctive therapy [54]. Transplantation of autologous bone marrow has recently facilitated the safe dose escalation of cyclophosphamide that resulted in long-term remission and prolonged patient survival in dogs [55]. However, autologous bone marrow transplantation is technically and logistically challenging to perform in a veterinary hospital setting which limits widespread application. With only a handful of FDA-approved or USDA-licensed veterinary oncology therapeutics currently available to veterinarians, there is a dire need for canine-specific treatment options (Table 1). To 
date, there is only one therapeutic with conditional FDA approval, rabacfosadine (Tanovea ${ }^{\circledR}-\mathrm{CA} 1$, VetDC), for the treatment of canine B-cell lymphoma. Rabacfosadine is an intravenously administered cytotoxic therapeutic agent which is a prodrug of the nucleotide analogue 9-(2phosphonylmethoxyethyl) guanine (PMEG). It effectively loads lymphoid cells while reducing levels of PMEG in plasma and target organs of toxicity. Tanovea-CA1 received conditional approval from FDA in January 2017 for the treatment of lymphoma in dogs and became available to veterinarians in the spring of 2017.

Immuno-oncology innovations are starting to make their way to veterinary oncology but remain limited with extremely sparse supporting data. Rituximab has been evaluated in dogs ex vivo and found not to bind or deplete canine B-cell lymphocytes [56,57]. Although an anti-CD20 (BLONTRESS $\AA$, Aratana) and an anti-CD52 (TACTRESS $\AA$, Aratana) monoclonal antibody are both fully licensed by the USDA, the company has stated that neither antibody is as specific to their respective targets as expected. No peer-reviewed data is available on either of these therapeutics to date and they are not commercially available. Another immunotherapeutic, Canine Lymphoma Vaccine, DNA (Boehringer Ingelheim) is currently available. This is a xenogeneic murine CD20 DNA therapeutic vaccine for use in dogs with B-cell lymphoma that was conditionally licensed by the USDA in 2015. No peer-reviewed data is available on this therapeutic to date. With current median survival times for dogs with lymphoma stagnant at less than one year, the opportunity for new, advanced, specific therapeutics remains clear.

\section{Preliminary data in dogs}

In a first ever canine study, Mason et al. [58], has reported successful mRNA electroporation of primary canine cells to generate CAR T-cells. In brief, a novel expansion methodology was developed that yields large numbers of canine T-cells from normal or lymphoma-diseased dogs. In this study, the authors had modified previous methods to activate and expand canine T cells ex vivo by using artificial antigen-presenting cells genetically modified to express human CD32 and canine CD86. These artificial antigen-presenting cells were loaded with a canine CD3 monoclonal antibody and used in combination with human IL2 and IL21 to preferentially expand CD8 ${ }^{+} \mathrm{T}$-cells. The mRNA electroporation procedure was utilized to express a first-generation, canine CD20-specific CAR in expanded T-cells as primary therapy. Treatment in 1 dog with relapsed B-cell lymphoma was well tolerated and led to a modest, but transient, anti-tumor activity, suggesting that stable CAR expression is required for sustained clinical remission. Other possible factors that could have contributed to the partial antitumor activity include limited CAR T-cell expansion and the development of canine antimouse antibodies directed against the murine scFv construct. Future studies are currently underway to investigate the clinical efficacy of a stably-transduced canine CAR 
332 T-cell line expressing fully canine, second-generation CAR constructs. Lymphodepleting 333 chemotherapy should also reduce the risk of inducing canine antimouse antibodies.

334 The high-cost of current human treatments, $\$ 475,000$ for tisagenlecleucel and $\$ 373,000$ for 335 axicabtagene ciloleucel [59] not including hospitalization and other costs, raises an important 336 potential challenge for the accessibility of this technology for use in dogs. New, non-viral genome 337 engineering tools are in development with the potential to reduce the cost of goods through obviating 338 the need for the generation of an infective engineered virus. For example, the Sleeping Beauty [60] 339 and piggyBac [61] transposons are in ongoing CAR T-cell clinical trials. In addition, gene editing 340 approaches for targeted knock-in using electroporation and ssDNA as donor [62] and new 341 approaches using enhanced dsDNA as donors for efficient targeted gene knock-in at diverse loci 342 [63] hold the potential for additional and more accessible, non-viral methods for CAR T-cell 343 generation.

\section{Comparative Oncology: An Opportunity to Accelerate Parallel Drug Development}

345 According to a recent report from the National Academy of Medicine [64], only 1 out of 10 oncology candidates that appear promising in preclinical mouse models are in fact effective and safe in human clinical trials. This overtly high attrition rate highlights the need for alternative models at the early stage of the Drug Research and Development lifecycle [65], as shown in other therapeutic areas [6671]. Although murine models have been extremely useful for studying the biology of cancer initiation, promotion and progression, mice typically do not faithfully represent many of the features constitutive of human cancer, including genomic instability, tumor heterogeneity and long periods of latency [72]. Additionally, study mice are often immunocompromised and bred in sterile laboratories, unlike domesticated dogs that share the same habitat and are exposed to same environmental carcinogens (e.g. UV light, pollution and food contaminants) as humans. Importantly, cancers develop spontaneously in dogs (i.e. without genetic manipulation) and in the context of an intact immunity with a syngeneic host and tumor microenvironment. Canine tumors typically have similar features to human malignancies, such as histological appearance, cytogenic abnormalities, therapeutic response, acquired resistance and background genetics [72]. Indeed, as the dog genome became available, multiple comparative genomics studies have shown significant homologies between canine and human cancer-associated genes, including MET, mTOR, KIT and TRAF3 [73]. Given the large number of breeds and their shared ancestry [74], inheritable germline mutations associated with cancer are easier to identify in purebred dogs than in human populations [75]. The outbred nature of dogs (relative to most murine models) contributes to their biological relevance for studying new cancer therapies. At the same time, the rapid progression of cancer 
365

366

367

368

369

370

371

372

373

374

375

associated with the shorter lifespan of dogs provides an opportunity to study the efficacy and safety of candidate therapeutic drugs in a much faster timeframe than clinical trials in human patients [76]. Biological similarities between canine and human cancer provide an impetus for the study of novel therapeutics in dog clinical trials (Fig. 4). In fact, the evaluation of oncology drugs in dogs with naturally occurring cancers is not new, with a few descriptions already available in the early 1970 s [77-79]. Over the last decade, multiple reports have demonstrated the relevance of the dog model to bridge the knowledge gap between murine experiments and human clinical trials, and exemplify the value of a comparative oncology approach to drug development [80-81].

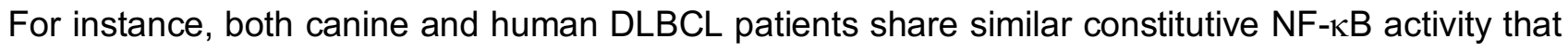
drives overexpression of anti-apoptotic NF-kB target genes which promote lymphocyte proliferation [82-83]. Studies indicate that administration of a targeted inhibitor of constitutive NF- $\kappa \mathrm{B}$ activity, NEMO Binding Domain (NBD), induces apoptosis of canine malignant B cells in vitro. Moreover, pilot trials have demonstrated intranodal administration of NBD peptide to dogs with relapsed B-cell lymphoma inhibits the expression of NF- $\mathrm{KB}$ target genes leading to reduced tumor burden [84]. In a separate Phase 1 clinical trial, these same investigators showed that NBD peptide administered intravenously is safe and effective at inhibiting constitutive NF- $\kappa \mathrm{B}$ activity in a subset of dogs with lymphoma [85]. Additionally, the use of established canine tumor cell lines has proven beneficial in studying tumor biology and pre-clinical therapeutics. A CD40 ligand-dependent culture system for canine malignant $B$-cells has been recently designed to test compounds for treatment in primary tumor samples from dogs and humans [86]. The tumor cells retain their original phenotype, clonality, and known karyotypic abnormalities after expansion and culture. This canine cell culture system is reported to be potentially robust to perform in vitro preclinical cytotoxic assays with primary B-cell malignancies.

The opportunity to synergize quantitative information available from humans and animals sharing clinical analogs to develop improved therapies for both species is known as 'Reverse Translation' [65]. A significant component of the success of comparative oncology in drug development is the creation of consortia that link drug development stakeholders to veterinary clinicians with access to tumor-bearing pet animals. This supports the implementation of clinical trials carried out in pets and the collection of high-quality clinical data and biologic specimens that are critical to defining PK/PD, tolerability and efficacy of novel therapeutic approaches destined for human use. To this end, the Comparative Oncology Program of the $\mathrm{NCl}$ has established a multi-center collaborative network of 24 veterinary academic partners known as the Comparative Oncology Trials Consortium [72,87]. The mission of the COTC is to answer biological questions geared to inform the development path of chemotherapeutics for future use in human cancer patients. The COTC operates as a platform for 
collaborative work between the $\mathrm{NCl}$ and extramural academic comparative oncology centers to design and execute clinical studies in dogs with cancer. Support for the oversight and management of the COTC comes from the NCl. Trial sponsors, most often pharmaceutical companies, support the costs associated with clinical studies in dogs in established COTC academic centers.

Several published examples of COTC trials exemplify the functionality and impact of such studies [87-89]. COTC trials do not focus exclusively on small molecules or biologic agents; instead they can be designed and implemented to answer a range of drug development questions that are key to the forward progress of an agent or group of candidate molecules, medical devices, or molecular profiling platforms. One such example illustrating the value of the dog model pertains to the development of the inflammatory cytokine IL-12 for the treatment of human malignant melanoma. The use of cytokines to enhance antitumor immunity has been recognized as an important immunomodulatory approach in cancer management. Yet, historically, the high risk for systemic toxicity presented by IL12 dosing had prevented development of this cytokine into a therapeutic drug. A strong genetic similarity exists between canine and human IL-12 (i.e. $84 \%$ homology for the ligand and $68 \%$ homology for the receptor), which motivated studies on the characterization of IL-12 PK/PD, efficacy, and toxicity in dogs with naturally occurring malignant melanoma [90]. Results showed that a fully human necrosis-targeted immunocytokine NHS-IL-12 could be safely administered subcutaneously to patients with malignant melanoma, while maintaining both systemic immunological and clinical activity. This was demonstrated by measuring serum IL-12 and other representative biomarkers (e.g. IL-10 and IFN-gamma) over time, and establishing PK/PD models of IL-12. These findings in dogs were key to guide the sponsor's decision to move forward with a Phase I clinical trial of this agent in humans. In turn, preliminary studies focusing on IL-12 gene electrotransfer in dog patients with melanoma have shown promising results for the treatment of spontaneous canine tumors [91-92]. With respect to CAR T-cell therapy research and development, the COTC infrastructure stands ready to implement cell-based trials to support pivotal go/no-go decision-making in the context of such agents' advancement for human use. Through strategic partnerships with study sponsors whom can provide the necessary cell manufacturing, quality control/assurance, and distribution support for such trials, the COTC can provide the requisite scientific input and execution for such trials to be carried out in the veterinary academic setting. Similarly, the COTC Pharmacodynamic Core laboratory can provide access to providers of canine-specific assay support for critical immunological assays such as flow cytometric assessment of immune cell subsets, gene expression profiling, 
432

433

434

435

436

437

438

439

440

441

442

443

444

445

446

447

\section{Conclusions}

CAR T-cells are one of the most promising development for the treatment of hematological malignancies. Specifically, CART19 cells have demonstrated unprecedented clinical results in human B-cell malignancies with two constructs being approved by the U.S FDA in 2017. Yet, the technology is still in its early phase and significant challenges need to be resolved before it can be used for large scale clinical trials. Obvious limitations include the complexity and costs (direct: related to the manufacturing, and indirect: related to hospital costs and patient care) of CAR T-cell therapy. The requirement for GMP materials and the individualized nature of the therapy are the main causes that drive-up the cost. The possibility to generate allogeneic off-the-shelf universal CAR Tcells [94] would lead to easier and more cost-effective manufacturing, reduced time to CAR T-cell infusion, improved CAR T health and faster translation of novel combination strategies with CAR Tcells in early phase clinical trials. In addition, the management of toxicities after CAR T-cell therapy requires specialized expertise and care level, making it available only in specialized tertiary centers. Strategies to modulate cytokine production after CAR T-cell therapy are being developed and could represent a new paradigm in the management of CAR-T cell-related side effects.

Importantly, there is currently a lack of robust preclinical models to recapitulate the microenvironment and toxicities following CAR T-cell therapy. Canine models have long been used in development of human cell therapies and allogeneic transplantation procedures and represent an attractive model to further investigate novel CAR T-cell strategies in liquid and solid tumors, as well as to develop novel off-the-shelf approaches. Preliminary data in dogs using a canine CD 20-specific CAR in expanded T-cells showed promising, but transient results. However, these preliminary findings lay the foundation for future studies in dogs where both tumor biology and the microenvironment more faithfully recapitulate that of humans.

Multiple studies are currently evaluating the effect of CAR T-cell therapy for the treatment of solid tumors, with modest results thus far [95]. Potential strategies to increase the efficacy of CAR T in this context include combinations with immune stimulants, secondary modifications of CAR T-cells, reengineering of the $\mathrm{T}$ cell, and specific targeting of the tumor microenvironment. Lastly, efforts are on the way to harness the immunosuppressive property of CAR T-cell for the treatment of autoimmune diseases, such as Inflammatory Bowel Disease (IBD) [96], thereby opening new avenues for comparative medicine and parallel drug development as the dog is a spontaneous animal disease model for IBD as well [97].

\section{$8 \quad$ Funding}

None. 


\section{Conflict of Interest}

466 JPM, SE, CJ, AJ, KA, WW and SSK are founders of LifEngine Animal Health Laboratories, Inc. SSK 467 is inventor on patents in the CAR T-cell therapy field that are licensed to Novartis.

468 This work was partially supported (AKL) by the Intramural Program of the National Cancer Institute, $469 \mathrm{NIH}$ (Z01-BC006161). The content of this publication does not necessarily reflect the views or policies 470 of the Department of Health and Human Services, nor does mention of trade names, commercial 471 products, or organizations imply endorsement by the U.S. Government.

\section{Author Contributions}

473 All authors (JPM, SE, CJ, AJ, KA, ABM, MK, SB WW, JAKL, SSK) have contributed to the writing of 474 the manuscript. JPM was responsible for the final production of the Commentary. All authors have 475 read and approved the final manuscript.

476 
477

478

479

480

481

482

483

484

485

486

487

488

489

490

491

492

493

494

495

496

497

498

499

500

501

502

503

504

505

506

507

508

509

510

511

\section{References}

1. Kaiser J, Couzin-Frankel J. Cancer immunotherapy sweeps Nobel for medicine. Science. 2018;362(6410):13.

2. Kenderian SS, Ruella M, Gill S, Kalos M. Chimeric antigen receptor T-cell therapy to target hematologic malignancies. Cancer Res. 2014;74(22):6383-9.

3. Yoon DH, Osborn MJ, Tolar J, Kim CJ. Incorporation of Immune Checkpoint Blockade into Chimeric Antigen Receptor T Cells (CAR-Ts): Combination or Built-In CAR-T. Int J Mol Sci. 2018;19(2). pii: E340.

4. Neelapu SS, Locke FL, Bartlett NL, Lekakis LJ, Miklos DB, Jacobson CA, Braunschweig I, Oluwole OO, Siddiqi T, Lin Y, Timmerman JM, Stiff PJ, Friedberg JW, Flinn IW, Goy A, Hill BT, Smith MR, Deol A, Farooq U, McSweeney P, Munoz J, Avivi I, Castro JE, Westin JR, Chavez JC, Ghobadi A, Komanduri KV, Levy R, Jacobsen ED, Witzig TE, Reagan P, Bot A, Rossi J, Navale L, Jiang Y, Aycock J, Elias M, Chang D, Wiezorek J, Go WY. Axicabtagene Ciloleucel CAR T-Cell Therapy in Refractory Large B-Cell Lymphoma. N Engl J Med. 2017;377(26):2531-2544.

5. Maude SL, Laetsch TW, Buechner J, Rives S, Boyer M, Bittencourt H, Bader P, Verneris MR, Stefanski HE, Myers GD, Qayed M, De Moerloose B, Hiramatsu H, Schlis K, Davis KL, Martin PL, Nemecek ER, Yanik GA, Peters C, Baruchel A, Boissel N, Mechinaud F, Balduzzi A, Krueger J, June $\mathrm{CH}$, Levine BL, Wood P, Taran T, Leung M, Mueller KT, Zhang Y, Sen K, Lebwohl D, Pulsipher MA, Grupp SA. Tisagenlecleucel in Children and Young Adults with BCell Lymphoblastic Leukemia. N Engl J Med. 2018;378(5):439-448.

6. Collins FS, Gottlieb S. The Next Phase of Human Gene-Therapy Oversight. N Engl J Med. 2018;379(15):1393-1395.

7. Seelig DM, Avery AC, Ehrhart EJ, Linden MA. The Comparative Diagnostic Features of Canine and Human Lymphoma. Vet Sci. 2016;3(2). pii: 11.

8. Bromberek JL, Rout ED, Agnew MR, Yoshimoto J, Morley PS, Avery AC. Breed Distribution and Clinical Characteristics of B Cell Chronic Lymphocytic Leukemia in Dogs. J Vet Intern Med. 2016;30(1):215-22.

9. Pule MA, Savoldo B, Myers GD, Rossig C, Russell HV, Dotti G, Huls MH, Liu E, Gee AP, Mei Z, Yvon E, Weiss HL, Liu H, Rooney CM, Heslop HE, Brenner MK. Virus-specific T cells engineered to coexpress tumor-specific receptors: persistence and antitumor activity in individuals with neuroblastoma. Nat Med. 2008;14(11):1264-70.

10. Till BG, Jensen MC, Wang J, Chen EY, Wood BL, Greisman HA, Qian X, James SE, Raubitschek A, Forman SJ, Gopal AK, Pagel JM, Lindgren CG, Greenberg PD, Riddell SR, Press OW. Adoptive immunotherapy for indolent non-Hodgkin lymphoma and mantle cell 
lymphoma using genetically modified autologous CD20-specific $T$ cells. Blood. 2008;112(6):2261-71.

11. Kershaw MH, Westwood JA, Parker LL, Wang G, Eshhar Z, Mavroukakis SA, White DE, Wunderlich JR, Canevari S, Rogers-Freezer L, Chen CC, Yang JC, Rosenberg SA, Hwu P. A phase I study on adoptive immunotherapy using gene-modified $T$ cells for ovarian cancer. Clin Cancer Res. 2006;12(20 Pt 1):6106-15.

12. Savoldo B, Ramos CA, Liu E, Mims MP, Keating MJ, Carrum G, Kamble RT, Bollard CM, Gee AP, Mei Z, Liu H, Grilley B, Rooney CM, Heslop HE, Brenner MK, Dotti G. CD28 costimulation improves expansion and persistence of chimeric antigen receptor-modified $\mathrm{T}$ cells in lymphoma patients. J Clin Invest. 2011;121(5):1822-6.

13. van der Stegen SJ, Hamieh M, Sadelain M. The pharmacology of second-generation chimeric antigen receptors. Nat Rev Drug Discov. 2015;14(7):499-509.

14. Turtle CJ, Hanafi LA, Berger C, Hudecek M, Pender B, Robinson E, Hawkins R, Chaney C, Cherian S, Chen X, Soma L, Wood B, Li D, Heimfeld S, Riddell SR, Maloney DG. Immunotherapy of non-Hodgkin's Iymphoma with a defined ratio of CD8+ and CD4+ CD19specific chimeric antigen receptor-modified T cells. Sci Transl Med. 2016;8(355):355ra116.

15. Lee DW, Kochenderfer JN, Stetler-Stevenson M, Cui YK, Delbrook C, Feldman SA, Fry TJ, Orentas R, Sabatino M, Shah NN, Steinberg SM, Stroncek D, Tschernia N, Yuan C, Zhang H, Zhang L, Rosenberg SA, Wayne AS, Mackall CL. T cells expressing CD19 chimeric antigen receptors for acute lymphoblastic leukaemia in children and young adults: a phase 1 doseescalation trial. Lancet. 2015;385(9967):517-528.

16. Rudd CE, Schneider H. Unifying concepts in CD28, ICOS and CTLA4 co-receptor signalling. Nat Rev Immunol. 2003;3(7):544-56.

17. Boomer JS, Green JM. An enigmatic tail of CD28 signaling. Cold Spring Harb Perspect Biol. 2010;2(8):a002436.

18. Sperling AI, Auger JA, Ehst BD, Rulifson IC, Thompson CB, Bluestone JA. CD28/B7 interactions deliver a unique signal to naive $\mathrm{T}$ cells that regulates cell survival but not early proliferation. J Immunol. 1996;157(9):3909-17.

19. Zhang H, Snyder KM, Suhoski MM, Maus MV, Kapoor V, June CH, Mackall CL. 4-1BB is superior to CD28 costimulation for generating CD8+ cytotoxic lymphocytes for adoptive immunotherapy. J Immunol. 2007;179(7):4910-8.

20. Carpenito C, Milone MC, Hassan R, Simonet JC, Lakhal M, Suhoski MM, Varela-Rohena A, Haines KM, Heitjan DF, Albelda SM, Carroll RG, Riley JL, Pastan I, June CH. Control of large, established tumor xenografts with genetically retargeted human T cells containing CD28 and CD137 domains. Proc Natl Acad Sci U S A. 2009;106(9):3360-5. 
21. Zhong XS, Matsushita M, Plotkin J, Riviere I, Sadelain M. Chimeric antigen receptors combining 4-1BB and CD28 signaling domains augment PI3kinase/AKT/Bcl-XL activation and CD8+ T cell-mediated tumor eradication. Mol Ther. 2010;18(2):413-20.

22. Fielding AK, Richards SM, Chopra R, Lazarus HM, Litzow MR, Buck G, Durrant IJ, Luger SM, Marks DI, Franklin IM, McMillan AK, Tallman MS, Rowe JM, Goldstone AH; Medical Research Council of the United Kingdom Adult ALL Working Party; Eastern Cooperative Oncology Group. Outcome of 609 adults after relapse of acute lymphoblastic leukemia (ALL); an MRC UKALL12/ECOG 2993 study. Blood. 2007;109(3):944-50.

23. Tavernier E, Boiron JM, Huguet F, Bradstock K, Vey N, Kovacsovics T, Delannoy A, Fegueux N, Fenaux P, Stamatoullas A, Tournilhac O, Buzyn A, Reman O, Charrin C, Boucheix C, Gabert J, Lhéritier V, Vernant JP, Dombret H, Thomas X; GET-LALA Group; Swiss Group for Clinical Cancer Research SAKK; Australasian Leukaemia and Lymphoma Group. Outcome of treatment after first relapse in adults with acute lymphoblastic leukemia initially treated by the LALA-94 trial. Leukemia. 2007;21(9):1907-14.

24. Gökbuget N, Stanze D, Beck J, Diedrich H, Horst HA, Hüttmann A, Kobbe G, Kreuzer KA, Leimer L, Reichle A, Schaich M, Schwartz S, Serve H, Starck M, Stelljes M, Stuhlmann R, Viardot A, Wendelin K, Freund M, Hoelzer D; German Multicenter Study Group for Adult Acute Lymphoblastic Leukemia. Outcome of relapsed adult lymphoblastic leukemia depends on response to salvage chemotherapy, prognostic factors, and performance of stem cell transplantation. Blood. 2012;120(10):2032-41.

25. Grupp SA, Kalos M, Barrett D, Aplenc R, Porter DL, Rheingold SR, Teachey DT, Chew A, Hauck B, Wright JF, Milone MC, Levine BL, June CH. Chimeric antigen receptor-modified T cells for acute lymphoid leukemia. N Engl J Med. 2013 Apr 18;368(16):1509-1518.

26. Maude SL, Frey N, Shaw PA, Aplenc R, Barrett DM, Bunin NJ, Chew A, Gonzalez VE, Zheng Z, Lacey SF, Mahnke YD, Melenhorst JJ, Rheingold SR, Shen A, Teachey DT, Levine BL, June $\mathrm{CH}$, Porter DL, Grupp SA. Chimeric antigen receptor T cells for sustained remissions in leukemia. N Engl J Med. 2014;371(16):1507-17.

27. Crump M, Neelapu SS, Farooq U, Van Den Neste E, Kuruvilla J, Westin J, Link BK, Hay A, Cerhan JR, Zhu L, Boussetta S, Feng L, Maurer MJ, Navale L, Wiezorek J, Go WY, Gisselbrecht $C$. Outcomes in refractory diffuse large B-cell lymphoma: results from the international SCHOLAR-1 study. Blood. 2017;130(16):1800-1808.

28. Kochenderfer JN, Yu Z, Frasheri D, Restifo NP, Rosenberg SA. Adoptive transfer of syngeneic $T$ cells transduced with a chimeric antigen receptor that recognizes murine CD19 can eradicate lymphoma and normal B cells. Blood. 2010 Nov;116(19):3875-86.

29. Roberts ZJ, Better M, Bot A, Roberts MR, Ribas A. Axicabtagene ciloleucel, a first-in-class CAR T cell therapy for aggressive NHL. Leuk Lymphoma. 2018;59(8):1785-1796. 
583

584

585

586

587

588

589

590

591

592

593

594

595

596

597

598

599

600

601

602

603

604

605

606

607

608

609

610

611

612

613

614

615

616

617

618

30. Advances in aggressive lymphoma from the 2017 American Society of Hematology Annual Meeting and Exposition. Clin Adv Hematol Oncol. 2018;16 Suppl 5(2):1-24.

31. News in Brief. Value in Using CAR T Cells for DLBCL. Cancer Discov. 2018;8(2):131-132.

32. Schuster SJ, Svoboda J, Chong EA, Nasta SD, Mato AR, Anak Ö, Brogdon JL, PruteanuMalinici I, Bhoj V, Landsburg D, Wasik M, Levine BL, Lacey SF, Melenhorst JJ, Porter DL, June $\mathrm{CH}$. Chimeric Antigen Receptor T Cells in Refractory B-Cell Lymphomas. N Engl J Med. 2017;377(26):2545-2554.

33. Rasche L, Weinhold N, Morgan GJ, van Rhee F, Davies FE. Immunologic approaches for the treatment of multiple myeloma. Cancer Treat Rev. 2017;55:190-199.

34. Jin Z, Xiang R, Qing K, Li X, Zhang Y, Wang L, Zhu H, Mao Y, Xu Z, Li J. The severe cytokine release syndrome in phase I trials of CD19-CAR-T cell therapy: a systematic review. Ann Hematol. 2018. doi: 10.1007/s00277-018-3368-8.

35. Park JH, Rivière I, Gonen M, Wang X, Sénéchal B, Curran KJ, Sauter C, Wang Y, Santomasso $B$, Mead E, Roshal M, Maslak P, Davila M, Brentjens RJ, Sadelain M. Long-Term Follow-up of CD19 CAR Therapy in Acute Lymphoblastic Leukemia. N Engl J Med. 2018;378(5):449459.

36. Lee DW, Kochenderfer JN, Stetler-Stevenson M, Cui YK, Delbrook C, Feldman SA, Fry TJ, Orentas R, Sabatino M, Shah NN, Steinberg SM, Stroncek D, Tschernia N, Yuan C, Zhang H, Zhang L, Rosenberg SA, Wayne AS, Mackall CL. T cells expressing CD19 chimeric antigen receptors for acute lymphoblastic leukaemia in children and young adults: a phase 1 doseescalation trial. Lancet. 2015;385(9967):517-528.

37. Liu D, Zhao J. Cytokine release syndrome: grading, modeling, and new therapy. J Hematol Oncol. 2018;11(1):121.

38. Davila ML, Riviere I, Wang X, Bartido S, Park J, Curran K, Chung SS, Stefanski J, BorquezOjeda O, Olszewska M, Qu J, Wasielewska T, He Q, Fink M, Shinglot H, Youssif M, Satter M, Wang Y, Hosey J, Quintanilla H, Halton E, Bernal Y, Bouhassira DC, Arcila ME, Gonen M, Roboz GJ, Maslak P, Douer D, Frattini MG, Giralt S, Sadelain M, Brentjens R. Efficacy and toxicity management of 19-28z CAR T cell therapy in B cell acute lymphoblastic leukemia. Sci Transl Med. 2014;6(224):224ra25.

39. Turtle CJ, Hanafi LA, Berger C, Gooley TA, Cherian S, Hudecek M, Sommermeyer D, Melville K, Pender B, Budiarto TM, Robinson E, Steevens NN, Chaney C, Soma L, Chen X, Yeung C, Wood B, Li D, Cao J, Heimfeld S, Jensen MC, Riddell SR, Maloney DG. CD19 CAR-T cells of defined CD4+:CD8+ composition in adult B cell ALL patients. J Clin Invest. 2016;126(6):212338.

40. Teachey DT, Lacey SF, Shaw PA, Melenhorst JJ, Maude SL, Frey N, Pequignot E, Gonzalez VE, Chen F, Finklestein J, Barrett DM, Weiss SL, Fitzgerald JC, Berg RA, Aplenc R, Callahan 
619

620

621

622

623

624

625

626

627

628

629

630

631

632

633

634

635

636

637

638

639

640

641

642

643

644

645

646

647

648

649

650

651

652

653

654

C, Rheingold SR, Zheng Z, Rose-John S, White JC, Nazimuddin F, Wertheim G, Levine BL, June $\mathrm{CH}$, Porter DL, Grupp SA. Identification of Predictive Biomarkers for Cytokine Release Syndrome after Chimeric Antigen Receptor T-cell Therapy for Acute Lymphoblastic Leukemia. Cancer Discov. 2016;6(6):664-79.

41. Giavridis T, van der Stegen SJC, Eyquem J, Hamieh M, Piersigilli A, Sadelain M. CAR T cellinduced cytokine release syndrome is mediated by macrophages and abated by IL-1 blockade. Nat Med. 2018;24(6):731-738.

42. Neelapu SS, Tummala S, Kebriaei P, Wierda W, Gutierrez C, Locke FL, Komanduri KV, Lin Y, Jain N, Daver N, Westin J, Gulbis AM, Loghin ME, de Groot JF, Adkins S, Davis SE, Rezvani $\mathrm{K}$, Hwu P, Shpall EJ. Chimeric antigen receptor T-cell therapy - assessment and management of toxicities. Nat Rev Clin Oncol. 2018;15(1):47-62.

43. Santomasso BD, Park JH, Salloum D, Riviere I, Flynn J, Mead E, Halton E, Wang X, Senechal B, Purdon T, Cross JR, Liu H, Vachha B, Chen X, DeAngelis LM, Li D, Bernal Y, Gonen M, Wendel HG, Sadelain M, Brentjens RJ. Clinical and Biological Correlates of Neurotoxicity Associated with CAR T-cell Therapy in Patients with B-cell Acute Lymphoblastic Leukemia. Cancer Discov. 2018;8(8):958-971.

44. Kochenderfer JN, Dudley ME, Kassim SH, Somerville RP, Carpenter RO, Stetler-Stevenson M, Yang JC, Phan GQ, Hughes MS, Sherry RM, Raffeld M, Feldman S, Lu L, Li YF, Ngo LT, Goy A, Feldman T, Spaner DE, Wang ML, Chen CC, Kranick SM, Nath A, Nathan DA, Morton KE, Toomey MA, Rosenberg SA. Chemotherapy-refractory diffuse large B-cell lymphoma and indolent B-cell malignancies can be effectively treated with autologous $T$ cells expressing an anti-CD19 chimeric antigen receptor. J Clin Oncol. 2015;33(6):540-9.

45. Gust J, Hay KA, Hanafi LA, Li D, Myerson D, Gonzalez-Cuyar LF, Yeung C, Liles WC, Wurfel M, Lopez JA, Chen J, Chung D, Harju-Baker S, Özpolat T, Fink KR, Riddell SR, Maloney DG, Turtle CJ. Endothelial Activation and Blood-Brain Barrier Disruption in Neurotoxicity after Adoptive Immunotherapy with CD19 CAR-T Cells. Cancer Discov. 2017;7(12):1404-1419.

46. Schiffman JD, Breen M. Comparative oncology: what dogs and other species can teach us about humans with cancer. Philos Trans R Soc Lond B Biol Sci. 2015;370(1673). pii: 20140231.

47. Gruntzig K, Graf R, Boo G, et al. Swiss Canine Cancer Registry 1955-2008: Occurrence of the most common tumour diagnoses and influence of age, breed, body size, sex and neutering status on tumour development. J Comp Pathol. 2016;155(2-3):156-170.

48. Dobson JM, Samuel S, Milstein $\mathrm{H}$, et al. Canine neoplasia in the UK: estimates of incidence rates from a population of insured dogs. J Small Anim Pract. 2002;43(6):240-6.

49. Richards KL and Suter SE. Man's best friend: what can pet dogs teach us about non-Hodgkin lymphoma? Immunol Rev. 2015;263(1):173-191. 
655

656

657

658

659

660

661

662

663

664

665

666

667

668

669

670

671

672

673

674

675

676

677

678

679

680

681

682

683

684

685

686

687

688

689

50. Marconato L, Gelain ME, Comazzi S. The dog as a possible animal model for human nonHodgkin lymphoma: a review. Hematol Oncol. 2013;31(1):1-9.

51. Ito D, Frantz AM, Modiano JF. Canine lymphoma as a comparative model for human nonHodgkin lymphoma: recent progress and applications. Vet Immunol Immunopathol. 2014;159(3-4):192-201.

52. Seelig DM, Avery AC, Ehrhart EJ, Linden MA. The comparative diagnostic features of canine and human Iymphoma. Vet Sci. 2016;3(2):11.

53. Richards KL, Motsinger-Reif AA, Chen HW, et al. Gene profiling of canine B-cell lymphoma reveals germinal center and post-germinal center subtypes with different survival times, modeling human DLBCL. Cancer Res. 2013;73(16):5029-39.

54. Chun R. Lymphoma: which chemotherapy protocol and why? Top Companion Anim Med. 2009;24(3):157-62.

55. Frimberger AE, Moore AS, Rassnick KM, Cotter SM, O'Sullivan JL, Quesenberry PJ. A combination chemotherapy protocol with dose intensification and autologous bone marrow transplant (VELCAP-HDC) for canine lymphoma. J Vet Intern Med. 2006;20(2):355-64.

56. Jubala CM, Wojcieszyn JW, Valli VE, et al. CD20 expression in normal canine B cells and in canine non-Hodgkin lymphoma. Vet Pathol. 2005;42(4):488-76.

57. Impellizeri JA, Howell K, McKeever KP and Crow SE. The role of rituximab in the treatment of canine lymphoma: an ex vivo evaluation. Vet J. 2006;171(3):556-8.

58. Panjwani MK, Smith JB, Schutsky K, Gnanandarajah J, O'Connor CM, Powell DJ Jr, Mason NJ. Feasibility and Safety of RNA-transfected CD20-specific Chimeric Antigen Receptor T Cells in Dogs with Spontaneous B Cell Lymphoma. Mol Ther. 2016;24(9):1602-14.

59. Sharma P, King GT, Shinde SS, Purev E, Jimeno A. Axicabtagene ciloleucel for the treatment of relapsed/refractory B-cell non-Hodgkin's lymphomas. Drugs Today (Barc). 2018;54(3):187198.

60. Kebriaei P, Singh H, Huls MH, Figliola MJ, Bassett R, Olivares S, Jena B, Dawson MJ, Kumaresan PR, Su S, Maiti S, Dai J, Moriarity B, Forget MA, Senyukov V, Orozco A, Liu T, McCarty J, Jackson RN, Moyes JS, Rondon G, Qazilbash M, Ciurea S, Alousi A, Nieto Y, Rezvani K, Marin D, Popat U, Hosing C, Shpall EJ, Kantarjian H, Keating M, Wierda W, Do KA, Largaespada DA, Lee DA, Hackett PB, Champlin RE, Cooper LJ. Phase I trials using Sleeping Beauty to generate CD19-specific CAR T cells. J Clin Invest. 2016;126(9):3363-76.

61. Ramanayake S, Bilmon I, Bishop D, Dubosq MC, Blyth E, Clancy L, Gottlieb D, Micklethwaite K. Low-cost generation of Good Manufacturing Practice-grade CD19-specific chimeric antigen receptor-expressing $\mathrm{T}$ cells using piggyBac gene transfer and patient-derived materials. Cytotherapy. 2015;17(9):1251-67. 
690

62. Roth TL, Puig-Saus C, Yu R, Shifrut E, Carnevale J, Li PJ, Hiatt J, Saco J, Krystofinski P, Li $H$, Tobin V, Nguyen DN, Lee MR, Putnam AL, Ferris AL, Chen JW, Schickel JN, Pellerin L, Carmody D, Alkorta-Aranburu G, Del Gaudio D, Matsumoto H, Morell M, Mao Y, Cho M, Quadros RM, Gurumurthy CB, Smith B, Haugwitz M, Hughes SH, Weissman JS, Schumann K, Esensten JH, May AP, Ashworth A, Kupfer GM, Greeley SAW, Bacchetta R, Meffre E, Roncarolo MG, Romberg N, Herold KC, Ribas A, Leonetti MD, Marson A. Reprogramming human $\mathrm{T}$ cell function and specificity with non-viral genome targeting. Nature. 2018;559(7714):405-409.

63. Wierson WA, Welker JM, Almeida MP, Mann CM, Webster DA, Weiss TJ, Torrie ME, Vollbrecht MK, Lan M, McKeighan KC, Ming Z, Wehmeier A, Mikelson CS, Haltom JA, Kwan, KM, Chien CB, Balciunas D, Ekker SC, Clark KJ, Webber BR, Moriarity B, Solin SL, Carlson DF, Dobbs DL, McGrail M, Essner JJ. GeneWeld: a method for efficient targeted integration directed by short homology. http://biorxiv.org/content/early/2018/10/03/431627.

64. National Cancer Policy Forum, Board on Health Care Services, Institute of Medicine, National Academies of Sciences, Engineering, and Medicine. The Role of Clinical Studies for Pets with Naturally Occurring Tumors in Translational Cancer Research: Workshop Summary. Washington (DC): National Academies Press (US); 2015.

65. Schneider B, Balbas-Martinez V, Jergens AE, Troconiz IF, Allenspach K, Mochel JP. ModelBased Reverse Translation Between Veterinary and Human Medicine: The One Health Initiative. CPT Pharmacometrics Syst Pharmacol. 2018;7(2):65-68.

66. Mochel JP, Gabrielsson J, Collard W, Fink M, Gehring R, Laffont C, Liu Y, Martin-Jimenez T, Pelligand L, Steimer JL, Toutain PL, Whittem T, Riviere J. Animal Health Modeling \& Simulation Society: a new society promoting model-based approaches in veterinary pharmacology. J Vet Pharmacol Ther. 2013 May 29. doi: 10.1111/jvp.12060.

67. Mochel JP, Fink M, Peyrou M, Soubret A, Giraudel JM, Danhof M. Pharmacokinetic/Pharmacodynamic Modeling of Renin-Angiotensin Aldosterone Biomarkers Following Angiotensin-Converting Enzyme (ACE) Inhibition Therapy with Benazepril in Dogs. Pharm Res. 2015;32(6):1931-46.

68. Mochel JP, Danhof M. Chronobiology and Pharmacologic Modulation of the ReninAngiotensin-Aldosterone System in Dogs: What Have We Learned? Rev Physiol Biochem Pharmacol. 2015;169:43-69.

69. Riviere JE, Gabrielsson J, Fink M, Mochel J. Mathematical modeling and simulation in animal health. Part I: Moving beyond pharmacokinetics. J Vet Pharmacol Ther. 2016;39(3):213-23.

70. Bon C, Toutain PL, Concordet D, Gehring R, Martin-Jimenez T, Smith J, Pelligand L, Martinez M, Whittem T, Riviere JE, Mochel JP. Mathematical modeling and simulation in animal health. 
Part III: Using nonlinear mixed-effects to characterize and quantify variability in drug pharmacokinetics. J Vet Pharmacol Ther. 2018;41(2):171-183.

71. Berger EP, Johannes CM, Jergens AE, Allenspach K, Powers BE, Du Y, Mochel JP, Fox LE, Musser ML. Retrospective evaluation of toceranib phosphate (Palladia $®$ ) use in the treatment of gastrointestinal stromal tumors of dogs. J Vet Intern Med. 2018 Oct 11. doi: 10.1111/jvim.15335.

72. Gordon I, Paoloni M, Mazcko C, Khanna C. The Comparative Oncology Trials Consortium: using spontaneously occurring cancers in dogs to inform the cancer drug development pathway. PLoS Med. 2009;6(10):e1000161.

73. Paoloni M, Khanna C. Translation of new cancer treatments from pet dogs to humans. Nat Rev Cancer. 2008;8(2):147-56.

74. Breen M, Modiano JF. Evolutionarily conserved cytogenetic changes in hematological malignancies of dogs and humans--man and his best friend share more than companionship. Chromosome Res. 2008;16(1):145-54.

75. Jacob JA. Researchers Turn to Canine Clinical Trials to Advance Cancer Therapies. JAMA. 2016;315(15):1550-2.

76. Khanna C, London C, Vail D, Mazcko C, Hirschfeld S. Guiding the optimal translation of new cancer treatments from canine to human cancer patients. Clin Cancer Res. 2009;15(18):56717.

77. Tsoi MS, Weiden PL, Storb R. Lymphocyte reactivity to autochthonous tumor cells in dogs with spontaneous malignancies. Cell Immunol. 1974 Sep;13(3):431-9.

78. Weiden PL, Storb R, Lerner KG, Kao GF, Graham TC, Thomas ED. Treatment of canine malignancies by $1200 \mathrm{R}$ total body irradiation and autologous marrow grafts. Exp Hematol. 1975;3(2):124-34.

79. Benjamini E, Theilen GH, Torten M, Fong S, Crow S, Henness AM. Tumor vaccines for immunotherapy of canine lymphosarcoma. Ann N Y Acad Sci. 1976;277(00):305-12.

80. Paoloni MC, Tandle A, Mazcko C, Hanna E, Kachala S, Leblanc A, Newman S, Vail D, Henry C, Thamm D, Sorenmo K, Hajitou A, Pasqualini R, Arap W, Khanna C, Libutti SK. Launching a novel preclinical infrastructure: comparative oncology trials consortium directed therapeutic targeting of TNFalpha to cancer vasculature. PLoS One. 2009;4(3):e4972.

81. Burton JH, Mazcko C, LeBlanc A, Covey JM, Ji J, Kinders RJ, Parchment RE, Khanna C, Paoloni M, Lana S, Weishaar K, London C, Kisseberth W, Krick E, Vail D, Childress M, Bryan JN, Barber L, Ehrhart EJ, Kent M, Fan T, Kow K, Northup N, Wilson-Robles H, Tomaszewski 
Inhibitors in Naturally Occurring Canine Lymphoma. Clin Cancer Res. 2018 Jul 30. doi: 10.1158/1078-0432.CCR-18-1498.

82. Davis RE, Brown KD, Siebenlist U, Staudt LM. Constitutive nuclear factor kappaB activity is required for survival of activated B cell-like diffuse large B cell lymphoma cells. J Exp Med. 2001;194(12):1861-74.

83. Karin M, Lin A. NF-kappaB at the crossroads of life and death. Nat Immunol. 2002;3(3):221-7.

84. Gaurnier-Hausser A, Patel R, Baldwin AS, May MJ, Mason NJ. NEMO-binding domain peptide inhibits constitutive NF-KB activity and reduces tumor burden in a canine model of relapsed, refractory diffuse large B-cell lymphoma. Clin Cancer Res. 2011;17(14):4661-71.

85. Habineza Ndikuyeze G, Gaurnier-Hausser A, Patel R, Baldwin AS, May MJ, Flood P, Krick E, Propert KJ, Mason NJ. A phase I clinical trial of systemically delivered NEMO binding domain peptide in dogs with spontaneous activated B-cell like diffuse large B-cell lymphoma. PLoS One. 2014;9(5):e95404.

86. Ito D, Frantz AM, Williams C, Thomas R, Burnett RC, Avery AC, Breen M, Mason NJ, O'Brien TD, Modiano JF. CD40 ligand is necessary and sufficient to support primary diffuse large Bcell lymphoma cells in culture: a tool for in vitro preclinical studies with primary B-cell malignancies. Leuk Lymphoma. 2012;53(7):1390-8.

87. LeBlanc AK, Breen M, Choyke P, Dewhirst M, Fan TM, Gustafson DL, Helman LJ, Kastan MB, Knapp DW, Levin WJ, London C, Mason N, Mazcko C, Olson PN, Page R, Teicher BA, Thamm DH, Trent JM, Vail DM, Khanna C. Perspectives from man's best friend: National Academy of Medicine's Workshop on Comparative Oncology. Sci Transl Med. 2016;8(324):324ps5. Drug Development. Clin Cancer Res. 2016;22(9):2133-8.

89. Paoloni MC, Tandle A, Mazcko C, Hanna E, Kachala S, Leblanc A, Newman S, Vail D, Henry C, Thamm D, Sorenmo K, Hajitou A, Pasqualini R, Arap W, Khanna C,Libutti SK. Launching a novel preclinical infrastructure: comparative oncologytrials consortium directed therapeutic targeting of TNFalpha to cancer vasculature. PLoS One. 2009;4(3):e4972.

90. Paoloni M, Mazcko C, Selting K, Lana S, Barber L, Phillips J, Skorupski K, Vail D, Wilson H, Biller B, Avery A, Kiupel M, LeBlanc A, Bernhardt A, Brunkhorst B, Tighe R, Khanna C. Defining the Pharmacodynamic Profile and Therapeutic Index of NHS-IL12 Immunocytokine in Dogs with Malignant Melanoma. PLoS One. 2015;10(6):e0129954.

91. Lampreht U, Kamensek U, Stimac M, Sersa G, Tozon N, Bosnjak M, Brozic A, de Sá Oliveira GG, Nakagawa T, Saeki K, Cemazar M. Gene Electrotransfer of Canine Interleukin 12 into Canine Melanoma Cell Lines. J Membr Biol. 2015;248(5):909-17. 
92. Lampreht Tratar U, Kos S, Kamensek U, Ota M, Tozon N, Sersa G, Cemazar M. Antitumor effect of antibiotic resistance gene-free plasmids encoding interleukin-12 in canine melanoma model. Cancer Gene Ther. 2018;25(9-10):260-273.

93. Paoloni M, Lana S, Thamm D, Mazcko C, Withrow S. The creation of the Comparative Oncology Trials Consortium Pharmacodynamic Core: Infrastructure for a virtual laboratory. Vet J. 2010;185(1):88-9.

94. Ruella M, Kenderian SS. Next-Generation Chimeric Antigen Receptor T-Cell Therapy: Going off the Shelf. BioDrugs. 2017;31(6):473-481.

95. Jaspers JE, Brentjens RJ. Development of CAR T cells designed to improve antitumor efficacy and safety. Pharmacol Ther. 2017;178:83-91.

96. Shin B, Kress RL, Kramer PA, Darley-Usmar VM, Bellis SL, Harrington LE. Effector CD4 T cells with progenitor potential mediate chronic intestinal inflammation. J Exp Med. 2018;215(7):1803-1812.

97. Otoni CC, Heilmann RM, García-Sancho M, Sainz A, Ackermann MR, Suchodolski JS, Steiner $\mathrm{JM}$, Jergens AE. Serologic and fecal markers to predict response to induction therapy in dogs with idiopathic inflammatory bowel disease. J Vet Intern Med. 2018;32(3):999-1008. hematological malignancies: advantages and challenges. Acta Pharm Sin B. 2018;8(4):539551. 


\section{Tables}

815 Table 1. Approved or Licensed Veterinary Oncology Therapeutics (U.S.)

\begin{tabular}{|c|c|c|c|c|c|c|}
\hline Trade Name & Compound Name & Company & Indication & $\begin{array}{l}\text { Regulatory Status, U.S. } \\
\text { (Year) }\end{array}$ & Species & $\begin{array}{l}\text { Commercial } \\
\text { Availability }\end{array}$ \\
\hline Blontress $®$ & $\begin{array}{l}\text { Canine lymphoma } \\
\text { MAb, B-cell }\end{array}$ & Aratana & B-cell lymphoma & $\begin{array}{l}\text { USDA } \\
\text { Licensed (2015) }\end{array}$ & Canine & No \\
\hline NA & $\begin{array}{l}\text { Canine lymphoma } \\
\text { vaccine, DNA }\end{array}$ & Merial/BI & B-cell lymphoma & $\begin{array}{l}\text { USDA } \\
\text { Conditional License (2015) }\end{array}$ & Canine & Yes \\
\hline NA & $\begin{array}{l}\text { Canine } \\
\text { osteosarcoma } \\
\text { vaccine, live listeria } \\
\text { vector }\end{array}$ & Aratana & Osteosarcoma & $\begin{array}{l}\text { USDA } \\
\text { Conditional License (2017) }\end{array}$ & Canine & Yes \\
\hline NA & $\begin{array}{l}\text { Feline interleukin-2 } \\
\text { immunomodulator }\end{array}$ & Merial/BI & $\begin{array}{l}\text { Primary stage I } \\
\text { fibrosarcoma }\end{array}$ & $\begin{array}{l}\text { USDA } \\
\text { Conditional License (2015) }\end{array}$ & Feline & Yes \\
\hline Immunocidin & $\begin{array}{l}\text { Mycobacterium cell } \\
\text { wall fraction }\end{array}$ & NovaVive & Mammary tumors & $\begin{array}{l}\text { USDA } \\
\text { Licensed (2009) }\end{array}$ & Canine & Yes \\
\hline Oncept $\circledast$ & $\begin{array}{l}\text { Canine melanoma } \\
\text { vaccine, DNA }\end{array}$ & Merial/BI & Melanoma & $\begin{array}{l}\text { USDA } \\
\text { Licensed (2010) }\end{array}$ & Canine & Yes \\
\hline Palladia ${ }^{\circledR}$ & Toceranib phosphate & Zoetis & $\begin{array}{l}\text { Grade II/III mast } \\
\text { cell tumor }\end{array}$ & $\begin{array}{l}\text { FDA } \\
\text { Approved (2009) }\end{array}$ & Canine & Yes \\
\hline Tactress $®$ & $\begin{array}{l}\text { Canine lymphoma } \\
\text { MAb, T-cell }\end{array}$ & Aratana & T-cell lymphoma & $\begin{array}{l}\text { USDA } \\
\text { Licensed (2016) }\end{array}$ & Canine & No \\
\hline $\begin{array}{l}\text { Tanovea®- } \\
\text { CA1 }\end{array}$ & $\begin{array}{l}\text { Rabacfosadine for } \\
\text { injection }\end{array}$ & VetDC & Lymphoma & $\begin{array}{l}\text { FDA } \\
\text { Conditional Approval } \\
(2017)\end{array}$ & Canine & Yes \\
\hline
\end{tabular}




\section{Figure Captions}

819 Figure 1. Evolution of the Chimeric Antigen Receptor (CAR). The $1^{\text {st }}$ CAR generation consists of a 820 receptor fused to a signaling domain composed of CD3 $\zeta$. The $2^{\text {nd }}$ generation includes an antigen821 binding domain, usually derived from a single chain variable fragment (scFv) or a protein receptor, a 822 hinge that connects the scFv to a transmembrane domain, a co-stimulatory domain (typically CD28) 823 and a $\mathrm{CD} 3 \zeta$ signaling domain. The $3^{\text {rd }}$ generation CAR includes 2 co-stimulatory domains along with 824 the activation domain, resulting in $\geq 3$ signaling domains in the CAR structure. Adapted from Zhao et 825 al. [98].

Figure 2. An overview of the basic steps of CAR T-Cell therapy production: (1) A patient (human, dog) or donor is undergoing leukapheresis to isolate T cells; (2) T cells are then genetically engineered to express CAR by gene transfection; (3) CAR-expressing T cells are expanded to a significant population size in vitro; (4) CAR T-cells are then introduced back into the patient.

Figure 3. In Chimeric Antigen Receptor (CAR) therapy, a patient's T cells are reprogrammed to specifically to seek-out and target cells expressing a particular antigen found on specific cancer cell types (Kenderian, 2014). Activation of T cells leads to direct killing of tumor cells through the release of cytolytic proteins, such as granzyme and perforin. Consult Figure 2 for additional technical details on CAR T-cell production.

838 Figure 4. Common cancers that have clinical analogues in humans and dogs. Approximately 4.2 839 million dogs (vs. 1.7 million human patients) get diagnosed with cancer each year, representing ca. 5,300 new canine cases for a standard 100,000 population size [46]. 

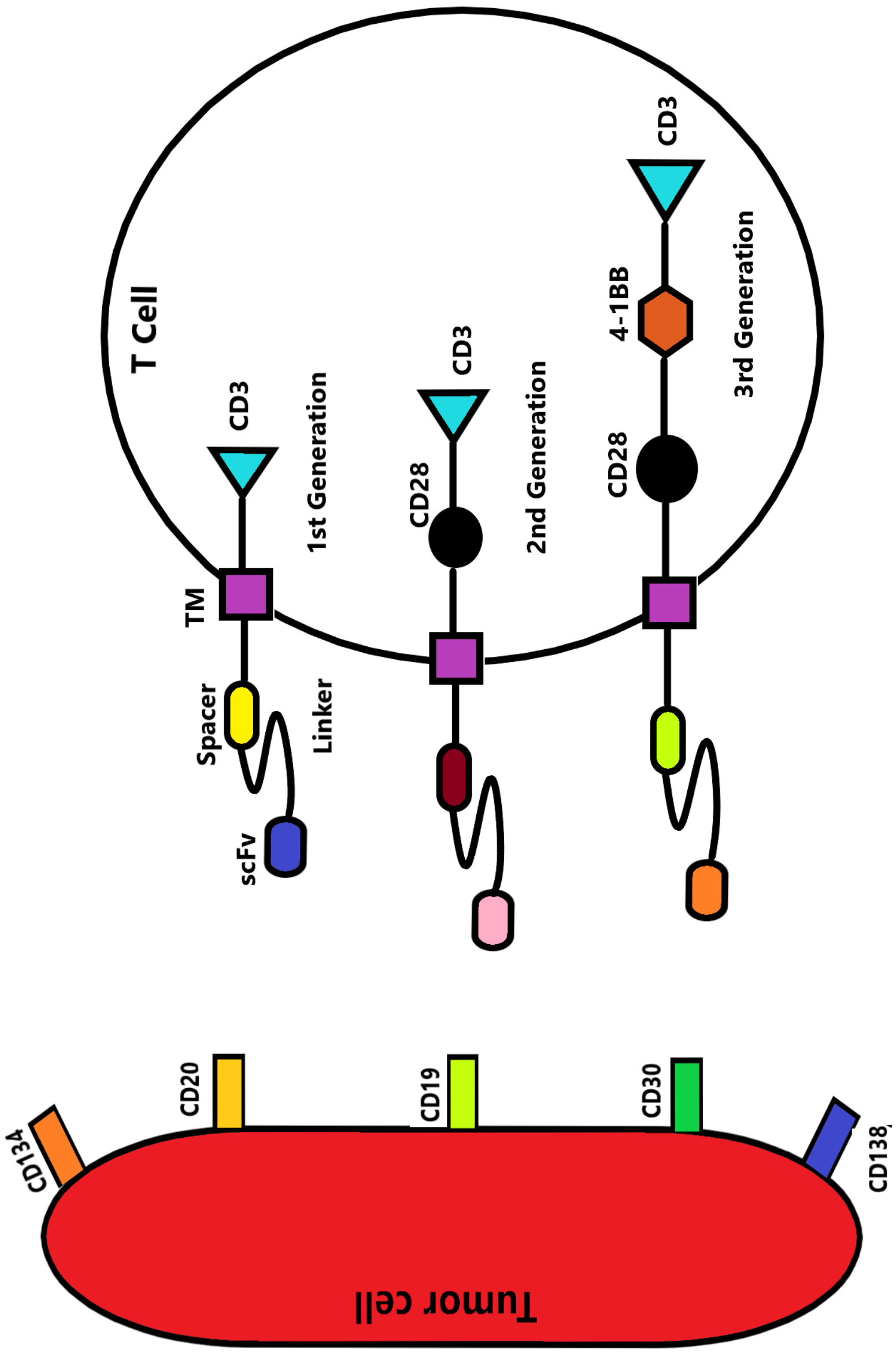


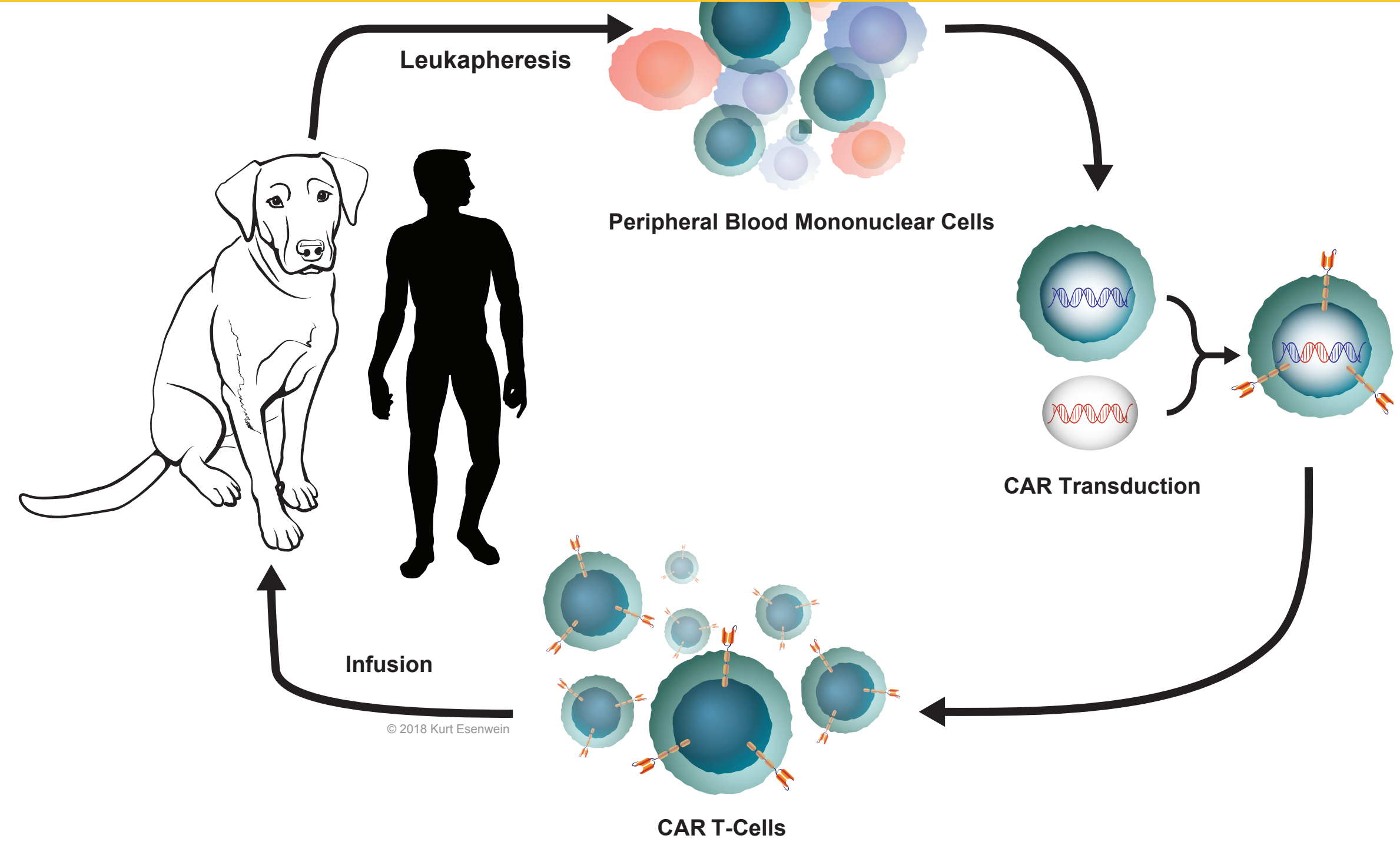




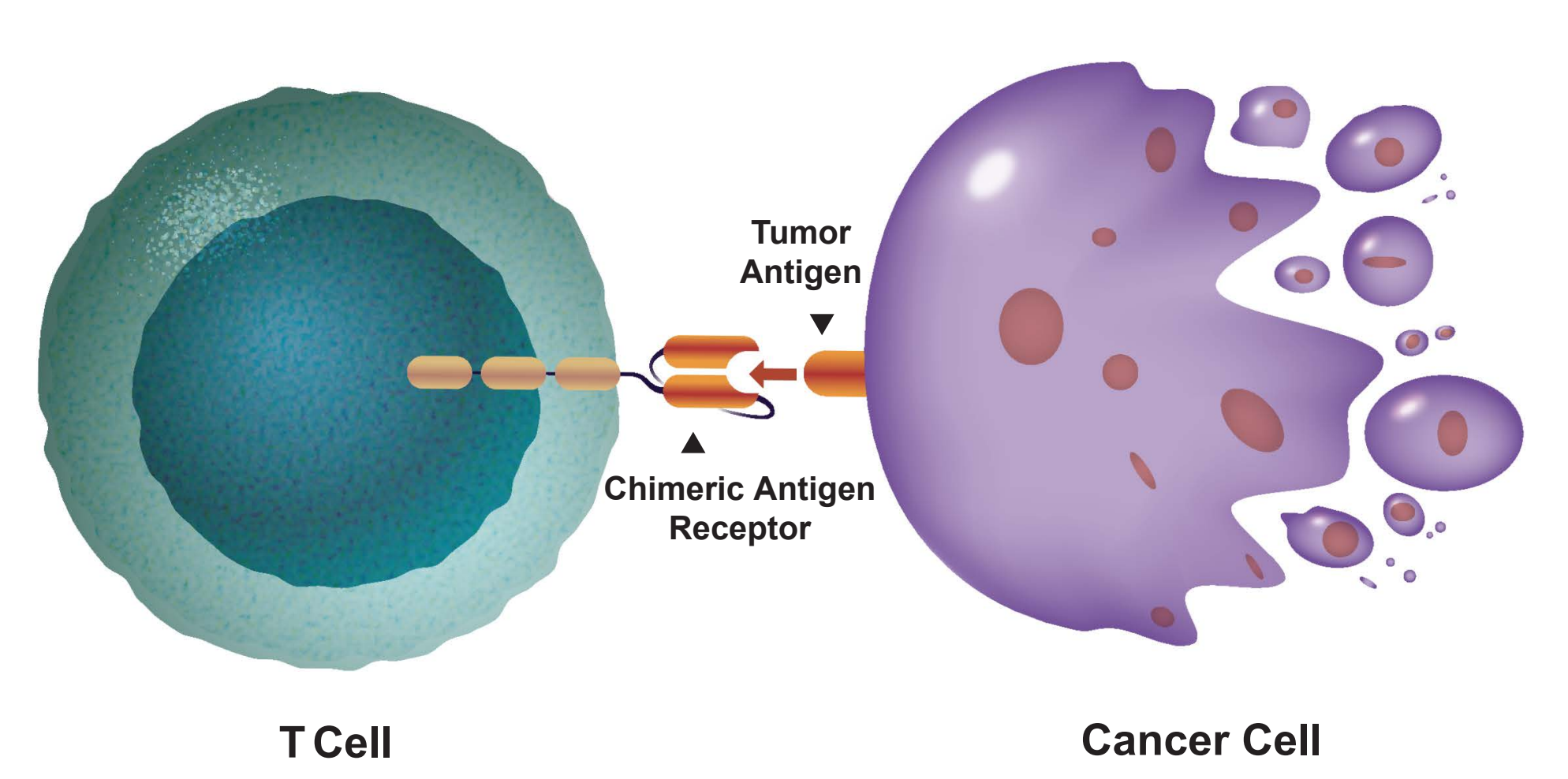

TCell

\author{
Cancer Cell
}




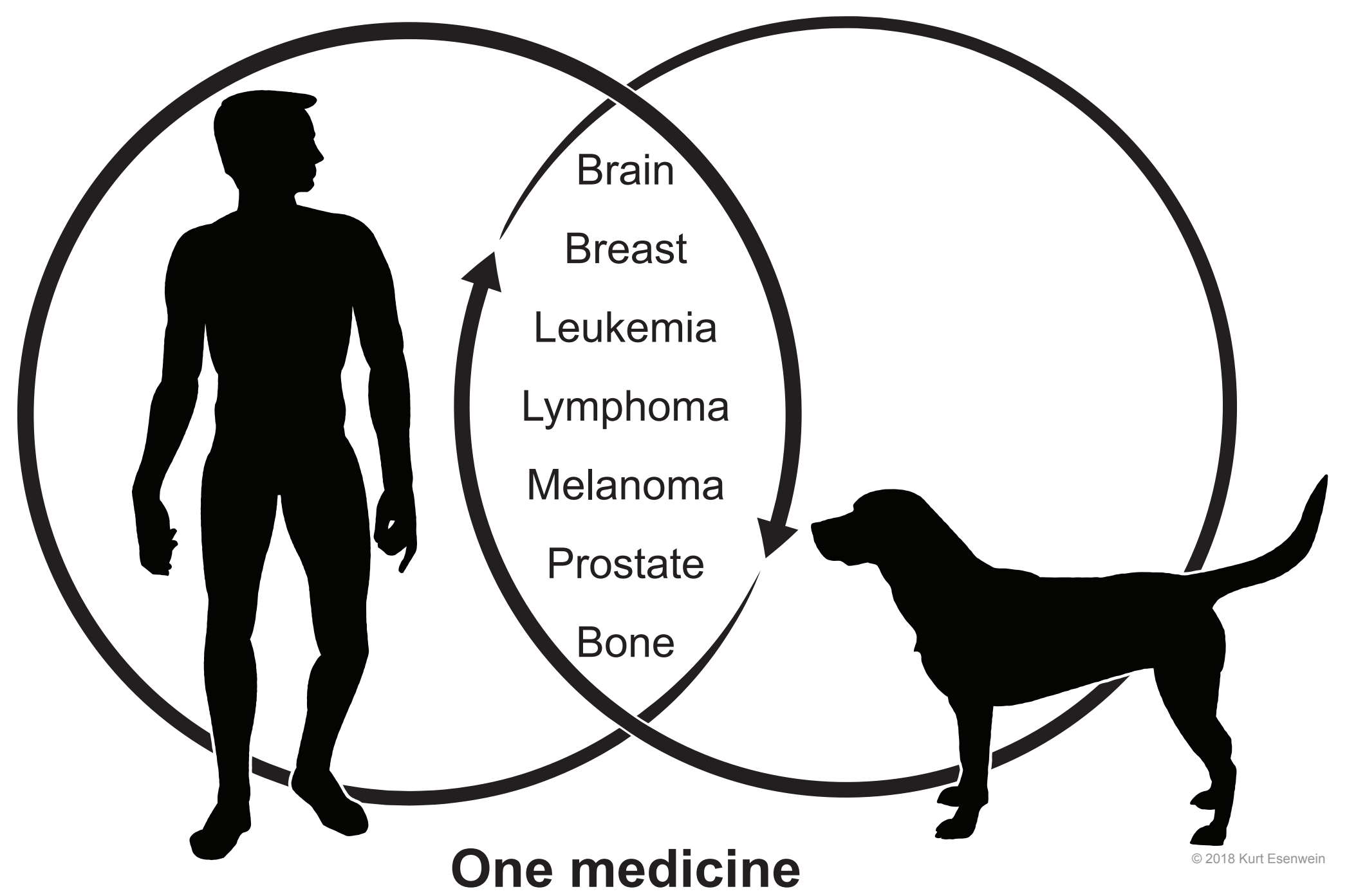

